\title{
THE APPLICABILITY OF ADOPTING EUROPEAN UNION'S INTEGRATION MODEL IN SOUTH ASIA: A COMPARATIVE ANALYSIS OF EUROPEAN UNION AND SOUTH ASIAN ASSOCIATION FOR REGIONAL COOPERATION
}

\author{
THUMIRA GUNASENA
}

\begin{abstract}
:
The European integration is three decades older than the South Asian integration. European Union stands as an outstanding regional body even though South Asian Association for regional Cooperation is still struggling to achieve the basic premises of economic integration. The aim of this paper is to comparatively analyze the two regional integrations and to identify how far is it appropriate to adopt the European integration model to accelerate the South Asian integration. One specific objective is to identify the core differences between the two regional settings and next objective is to determine the theoretical relevance of certain existing theories in describing the two integration processes. Another specific objective is to evaluate the suitability of adopting European Union model in South Asia and to recommend necessary reforms for better integration in South Asia. Data triangulation method has been used to accumulate secondary data from multiple sources available in electronic and printed form including books, journals, web, reports, historical records and treaties. Qualitative content analysis has been used since this is a documentary analysis and Content analysis evaluate document texts and to test theoretical relevance to understand data more comprehensively and scientifically. It will test prevailing theories in different contexts when compare the categories of different settings.

Key findings depicts that there is a sharp diversity between the European Union and South Asia in terms of trade, economic development, human development, industrialization, urbanization, trade liberalization, income levels, poverty alleviation and political integration. Amidst these differences the applicability of adopting the European model proves to be a failure due to many factors. The democratic nature of the countries and their practice of free market economic policies along with the successful resolutions for political tensions in Europe significantly caused the long term success of European integration whereas South Asian countries are suffering from huge diversities in economic, geographic, cultural, trade and military terms within the region and hesitate to co-operate with one another due to these differences. Indo-Pakistan political tensions blended with smaller states' fear psychosis of Indian hegemony is the greatest constraint for better integration in South Asia. South Asia required rearranging the structure of its regional organization and opening avenues to discuss contentious issues among member states. Establishment of real democracies and reliable interactions among people to people contacts while adopting more comprehensive free market economic policies domestically would facilitate the economic and political integration of South Asia in the future.
\end{abstract}

\section{Keywords:}

European Union, South Asian Association for Regional Cooperation, Economic integration, political integration 
JEL Classification: Y90

\section{Authors:}

THUMIRA GUNASENA, University of Kelaniya , Sri Lanka, Email: thumira@gmail.com

\section{Citation:}

THUMIRA GUNASENA (2016). The applicability of adopting European Union's integration model in South Asia: A comparative analysis of European Union and South Asian Association for Regional Cooperation . International Journal of Social Sciences, Vol. V(2), pp. 19-43.,

10.20472/SS.2016.5.2.002 


\section{Introduction}

Post Second World War and Post- Cold War period were significant in the growth and rapid diffusion of regional organizations in the world due to many reasons. One such explicit reason was that many countries expected to enhance their economic development through regional cooperation. After experiencing bitterness of two major World Wars, the European leaders and people understood the gravity of disastrous war and they determined to avoid another World War to prevent such material and human loss in the future. As a result the United Nations was created and the arrival of new regional co-operations was also very much evident during the Post Second World War period. The diffusion of regional organizations was not only a result of the Second World War.

There were other explicit and implicit causes behind that. The collapse of Soviet Russia was one such fundamental cause which encouraged the regional cooperation among Eastern European nations which was supported by many of the Western European countries those who appreciate capitalism and democracy. The trade liberalization began to spread all around the world and the collapse of tight bipolarity was one major reason for this. This transformation in the international order increased the interdependency among many countries in the world.

As a result of rapid population growth and their complicated necessities which were beyond the fundamental needs of a human being caused the increase in the demand for goods and services. The increased consumption levels in the world could not be encountered by single country to satisfy the domestic needs and wants of its people. It ultimately created the interdependency among many nations. The developed countries required much of raw materials, cheap labour and larger markets to sell their good whereas under developed nations required technical, capital and finance support, market entries as well as direct and indirect investments, from the developed countries. As long as one country could not meet all the domestic demands within its boundaries, this interdependency pushed both developed and under developed nations towards the regional cooperation. Many of the world leaders began to adjust their domestic policies suitable for this transition in terms of economic liberalization while globalization accelerated this process further.

The European integration is among the most significant regional cooperation in the world since the initiation of European Union (EU). In case of South Asia the regional integration was a slow process and South Asian Association for Regional Co-operation (SAARC)

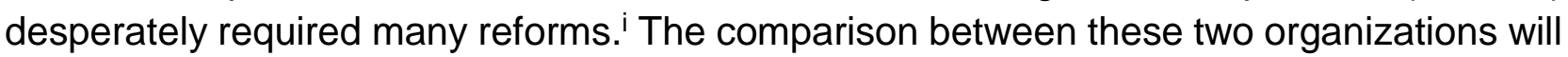
explained the causes for the success of European integrations and causes for failures of the South Asian integration along with the lessons to be learnt by the South Asian countries to accelerate positive integration. One could argued out that European and South Asian integration carried less similarities and their differences are huge and therefore it is not the 
most suitable comparison. Yet this effort is to identify what makes these core differences between European and South Asian regional integration along with the possible adjustments that can be made to accelerate South Asian integration by considering European integration as an example. There could be certain policy areas possible to adopt by the South Asian countries which have brought success in the Europe. This paper aims at fulfilling above requirements and also it aims at providing an academic discussion by adopting a theoretical discussion in explaining the regional integration of the two regional territories.

\section{Methodology}

Secondary data collected through data triangulation method available in both printed and electronic form in multiple data sources such as in electronic and printed form including books, journals, web, reports, historical records and treaties will be analyzed using theories through a deductive content analysis. It will test prevailing theories in different contexts when compare the categories during different time settings. It will suggest how the existing theory could be developed in order to explain certain new emerging data categories not fit in to the existing theoretical concepts independent of the theory. Content analysis evaluate document texts and to test theoretical relevance to understand data more comprehensively and scientifically.

\section{Theoretical framework}

Among the integration theories both neo-functionalism and federalism support the European integration." "Both neo-functionalism and Liberal-intergovernmentalism are macro-level theories of international relations, which are designed to describe, clarify and predict the European integration as a process." (Moga, 2009, p.796). Ernst Haas ${ }^{\mathrm{iii}}$ who is considered as the father of neo-functionalism believed that spill-over effect of the nonpolitical areas in to the politically sensitive areas would lead to the creation of a new political community. Haas (1958) emphasized that as a result of transferring the loyalties of various domestic groups in to the supra national body, they began to enjoy more benefits which made them understand that that the new center or the supra national institution is better than the pre- existed sovereign state. For Haas "political integration is the process whereby political actors in several distinct national settings are persuaded to shift their loyalties, expectations and political activities toward a new center, whose institutions possess or demand jurisdiction over the pre-existing national states" (Moga, 2009, p.797).

In case of European Union the spill-over effect of economic sectors and then the politically sensitive areas depicts the validity of neo-functionalism in describing the European integration. But in case of South Asia the economic integration began in mid-1990s and it 
was a deliberate effort that initiated a Free Trade Agreement among South Asian countries. The positive spill-over in these economic sectors and the political sectors seem to be impossible under the current circumstances of existing political tensions among the South Asian countries.

The ultimate goal of the European integration is to create a federalist state and according to (Moga, 2009, p.797) "the founding fathers of the $E C^{1}$ - Jean Monnet, the French Planning Commissioner, and Robert Schuman, the French Foreign Minister - were essentially pragmatic federalists". The federalist framework is workable in the European system in which most of the people are homogeneous, and their cultural identities do not clash with one another at extreme level. Moreover these countries are democratic and they have successfully adopted capitalism with trade liberalization. Similar natures of economic and political systems in their countries stand as positive encouragements to initiate the federalist idea. Even though federalist approach is much appropriate for the European system still the political conditions are not perfectly conducive to adopt the federal system in Europe. Accordingly Castaldi (2007, p.29 ) added that "the federalists had to accept that their ultimate goal in Europe was not attainable immediately, and that a long struggle would be required to create the conditions in which it was possible. In South Asia many of the moral imperatives required to establish a federal system is very much lacking in the sense that their diversity is huge which resulted in creating conflict ridden environment in the region among its member states. Adding to these hurdles, many of the member states are not democratic and sufficient efforts were not taken to encourage trade liberalization. South Asian countries are more introvert in the sense that their individual expectations are stronger than establishing cooperate goals to develop as a region. These clashes of interests in South Asia made it difficult to believe that a federalist framework would fit in to the South Asian system.

Moravcsik and Schimmelfennig (2009, p.67) explained that "Liberal-intergovernmentalism (LI) has acquired the status of a baseline theory in the study of regional integration". According to them Liberal-intergovernmentalism composed with multiple integration theories since single factor cannot alone describe a complex concept of integration. Liberalintergovernmentalism considers states as rational actors thereby make decisions choose the best alternative option for to maximize the benefits. In case of establishing international organizations Moravcsik and Schimmelfennig (2009, p.68) added that the "agreement to cooperate, or to establish international institutions is explained as a collective outcome of interdependent (strategic) rational state choices and intergovernmental negotiations". iv Moravcsik (1991) describes the member states are too much concerned about their national interests and they are reluctant to transfer the sovereignty powers to a supra national body. They prevent from transferring the supreme authority to central institutions

${ }^{1}$ European Community 
since they refuse to weaken their sovereignty powers. Therefore they encourage intergovernmental institutions and prefer to work through such institutions. Accordingly Moravcsik (1993, p.474) pointed out "the state behavior reflects the rational actions of governments constrained at home by domestic societal pressure and abroad by their strategic environment". Moravcsik (1993) further stressed when member states have similar goals and preferences they tend to transfer their sovereignty to the supra national body to achieved these common goals since the advantages of such transfer is much more beneficial for them.

Moravcsik (1998) describes three- stages framework to explain the decision making of states on cooperating internationally. The national preference making, bargaining and institutional choice are three stages and each stage has been described using different theories. In case of describing the European integration Moravcsik and Schimmelfennig (2009, p.69) explained that "EU integration can be best understood as a series if rational choices made by national leaders. These choices responded to constraints and opportunities stemming from the economic interests of powerful domestic constituents, the relative power of states stemming from asymmetrical interdependence and the role of institutions in bolstering the credibility of interstate commitments." Pollack (2000) further describing the national preferences of the states argued that these preferences do not derive from security concerns related to international system but they are domestically generated. The author pointed out that according to Moravcsik major intergovernmental bargains in EU were not concluded as a result of spillover effect in the earlier integration as described by neo-functionalist but "rather by a gradual process of preference convergence among the most powerful member states". (Pollack, 2000, p.5). By contrast South Asian countries were neither collaborated for common economic purposes nor did they form a common preference to achieve common goals. There are more concerned with security goals and the fear psychosis of smaller states towards the regional powers and the clashes between the regional powers hugely constrained the regional integration process.

\section{Comparison between European Union and South Asian Association for Regional Cooperation}

The European nations' first effort on creating the European Union could be traced back to 1950s with the initiation of European Coal and Steel Community in 1952 by signing the Treaty of Paris in $1951^{\mathrm{v}}$. In case of South Asian countries since they obtained independence in 1940s it took more than four decades time to establish a regional body for the mutual cooperation among South Asian countries. The South Asian Association for Regional Cooperation which was the main regional body in South Asia was established in 1985 and by this time the European Union had planned for Single Market entry and signed the Single European Act ${ }^{\mathrm{vi}}$ in 1987. By 1990 the European Community decided to open the 
borders for free movement of people and they signed the Schengen Agreement ${ }^{\mathrm{vii}}$ which abolished the visa requirements for its member states and granted multiple entry visa for their citizens. It was only around 1995 that the SAARC attempted to sign a Free Trade Agreement known as South Asian Preferential Trade Agreement which is slightly the very first step in the integration scale. Even before the signing of the first Free Trade Agreement in South Asia the European Nations established the Economic Union in 1992 by signing the Maastricht Treaty viii and European Union was created with that. By 1993 the Single Market was created while SAARC was attempting to sign its free trade agreement in 1995. Closer observation on the time line of the two associations clearly define that SAARC was too much lagging behind in its progress compared to the European Union whereas the latter is pertained with very rich experiences in regional cooperation South Asia is still struggling to overcome many hurdles on its way for better cooperation. Apart from the different levels of regional integration experienced by two organizations the power asymmetry in the South Asian region and its sharp diversity is very much different from the European region. ${ }^{\text {ix }}$

Table 01: Military expenditure by South Asian countries, in current US\$ (2013 to 2014)

\begin{tabular}{|l|c|c|}
\hline Country & 2013 & 2014 \\
\hline Afghanistan & 217 & 268 \\
\hline Bangladesh & 1818 & 2010 \\
\hline India & 47403 & 49968 \\
\hline Nepal & 277 & 305 \\
\hline Pakistan & 7645 & 8537 \\
\hline Sri Lanka & 1835 & 1843 \\
\hline
\end{tabular}

Source: Own adjustment based on http://www.sipri.org/research/.../milex/milex_database/milex-data1988-2014

The above Table 01 depicts the differences among South Asian countries in their military expenditures. According to Table 01 data, the military expenditure of all the countries has increased from 2013 to 2014 . But the level of military expenditure by each country depicts contrasting values and the following Figure 01 clearly displays the differences in their military expenditures. 
Figure 01: Military expenditure by South Asian countries (2014)

\section{Military Expenditure 2014}

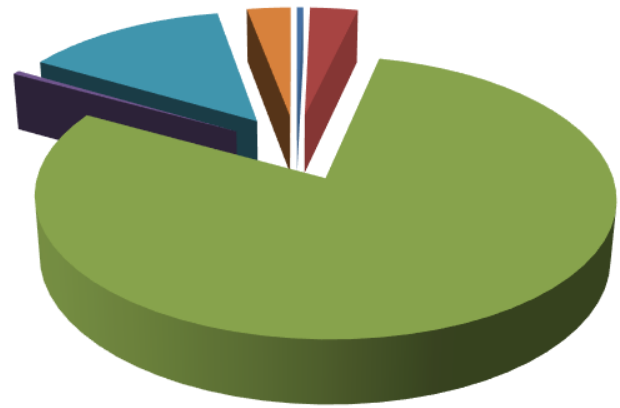

$$
\begin{aligned}
& \text { - Afghanistan } \\
& \text { Bangladesh } \\
& \text { India } \\
& \text { - Nepal } \\
& \text { Pakistan } \\
& \text { Sri Lanka }
\end{aligned}
$$

Source: Own adjustment based on SIPRI data, http://www.sipri.org/research/.../milex/milex_database/milex-data-1988-2014.

The vivid contrast among the military expenditure of the South Asian countries connotes that the India spends huge amount of money on military requirements while the smaller nations claim very little compared to India as their military expenses. The importance of analyzing such a difference is that it reveals all the South Asian countries are not equally strong in military terms and the Indian military power works as a negative factor in emanating security dilemma for the rest of its neighbor countries and they prevent from extending cooperation with India with fear of strengthening its hegemonic position in South Asia. Therefore this diversity among the South Asian countries is a barrier for their mutual cooperation since the power asymmetries prevailing among the member states greatly constrained their cooperation towards better regional grouping. Not only the military power but even in terms of economic development there are significant gaps among the South Asian nations.

Table 02: Gross Domestic Product (GDP) of the South Asian countries (2014)

\begin{tabular}{|l|l|}
\hline Country & GDP in Millions of US\$ \\
\hline India & $2,144,338$ \\
\hline Pakistan & 246,876 \\
\hline Bangladesh & 173,819 \\
\hline Sri Lanka & 74,941 \\
\hline Afghanistan & 20,842 \\
\hline Nepal & 19,636 \\
\hline Maldives & 3,032 \\
\hline Bhutan & 1,821 \\
\hline
\end{tabular}

Source: Own adjustment based on World Development Indicators database, World Bank, 18 September 2015 
The power asymmetries of South Asia work as a hurdle in developing mutual cooperation among them and apart from the huge differences in terms of military capabilities, the Table 02 depicts that the value of GDP also has increased this diversity among the South Asian countries. India and Pakistan emerged as the two economic powers of the region but India surpassed even Pakistan by huge difference in terms of GDP. India claimed the $9^{\text {th }}$ place in world's GDP ranking in year 2014 according to the World Bank data and Pakistan claimed only the $43^{\text {rd }}$ place in this ranking. Therefore the gap between the two largest economies in the region is too much and the smaller economies required rapid growth in order to dismiss this inequality in the GDP. Figure 02 graphically expressed these differences very clearly as follows.

Figure 02: Gross Domestic Product (GDP) of the South Asian countries (2014)

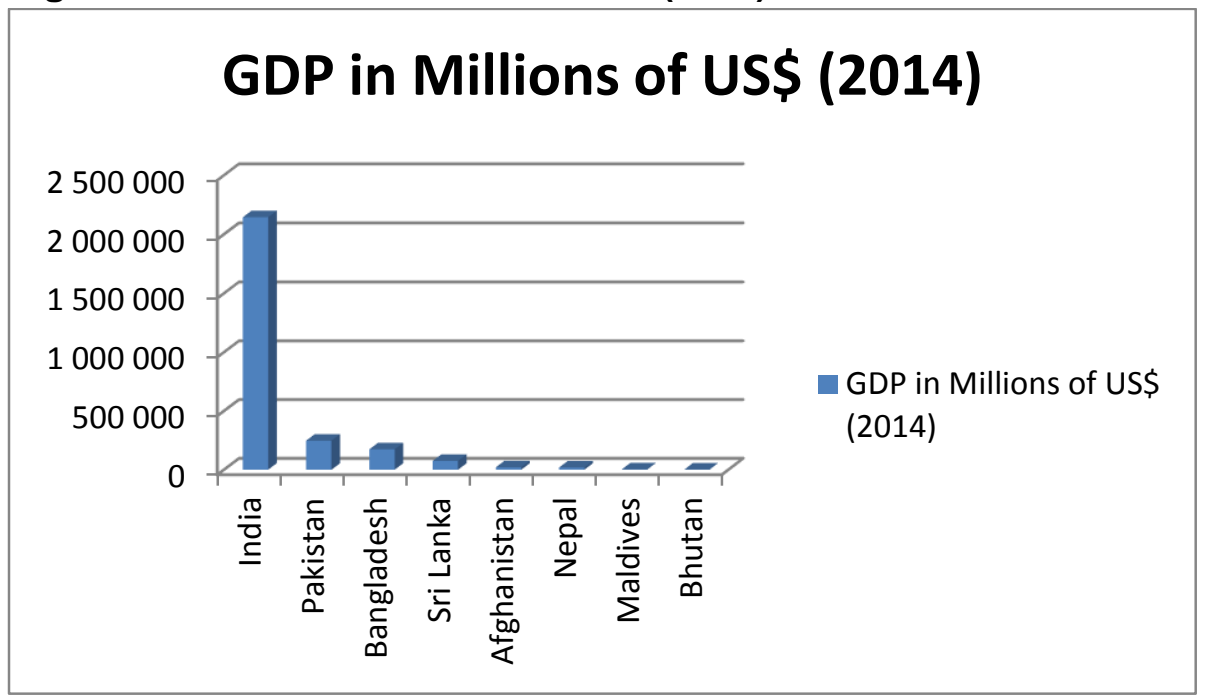

Source: Own adjustment based on World Bank data 2015

The graphical interpretation of the GDP of South Asian countries clearly shows that the Afghanistan, Nepal, Maldives and Bhutan claimed for very low value in their GDP compared to the regional power of India. Even Pakistan which claims for the second largest economy in South Asia is very much lagging behind the Indian economy. This is one of the reasons why Pakistan does not sincerely commit for the economic integration in South Asia since it fears that this cooperation would open up more avenues for India to grow faster than this. Similarly smaller states also feared that Indian economy will grow at their expense and this fear psychosis constrained the greater cooperation in South Asia. Kher (2012, p.11) pointed out that in South Asia this power asymmetry is one the crucial challenges for better cooperation and "As per the power centrist view, power, both military and economic, is the most critical determining factor in regional integration arrangements."

When compare the two regions of South Asia and Europe the difference between the levels of their economic development proved to be very distant. Despite the fact that India is the only strong economy in the South Asian region when compared to the European Union, 
their differences are very much significant. For instance the World Bank has identified various income levels and the countries in the world have been grouped under these different income categories in accordance with their Gross National Income (GNI) per capita value. The following are the various income levels introduced by the World Bank.

1. High income

2. Heavily indebted poor countries (HIPC)

3. Low income

4. Lower middle income

5. Low \& middle income

6. Middle income

7. Upper middle income

According to the World Bank data 2014 all the South Asian countries belong in to the Low and middle income level which claims only GNI per capita value of US\$4,226. Moreover the data depicts that Afghanistan included in to the heavily indebted poor countries (HIPC) category and the overall conclusion is that all the South Asian countries include in to low level of income category compared to the European Union member states.

Table 03: EU countries belong to High Income Level category (2014)

\begin{tabular}{|ll|}
\hline EU countries belong to High Income Level category \\
\hline 1. & Latvia \\
\hline 2. & Lithuania \\
\hline 3. & Luxembourg \\
\hline 4. & Austria \\
\hline 5. & Malta \\
\hline 6. & Netherlands \\
\hline 7. & Belgium \\
\hline 8. & Poland \\
\hline 9. & Portugal \\
\hline 10. Croatia \\
\hline 11. Cyprus \\
\hline 12. Czech Republic \\
\hline 13. Denmark \\
\hline 14. Estonia \\
\hline 15. Finland \\
\hline 16. Slovakia \\
\hline 17. France \\
\hline 18. Slovenia \\
\hline 19. Spain \\
\hline 20. Germany \\
\hline 21. Greece \\
\hline 22. Sweden \\
\hline
\end{tabular}




\begin{tabular}{|l|}
\hline 23. Ireland \\
\hline 24. United Kingdom \\
\hline 25. Italy \\
\hline
\end{tabular}

Source: Own adjustment based on http://data.worldbank.org/income-level/HIC

By contrast out of 28 member states in European Union 25 of them belong in to the High Level income category which claims for GNI per capita value of $\$ 38,317$. The above Table 03 indicates the number of European member states belong to the High Level income category in 2014.

The poverty rate of the two regions also significantly differs from one another. This is another outstanding difference between the two regions. In year 2012 the poverty headcount ratio at $\$ 1.90$ a day depicts that this ratios is only $2.1 \%$ in Europe and Central Asia while it accounts for $18.8 \%$ in South Asia. (http://data.worldbank.org/country). In 2015 according to the Multidimensional Poverty Index 2015 "as a region, Europe and Central Asia has the lowest poverty rates and is the most uniform region, with all countries having a headcount ratio of $2 \%$ or less except few Central Asian countries". (www.ophi.org.uk/multidimensional-poverty-index). According to the Multidimensional Poverty Index 2015 "the Global MPI has national estimates for 15 countries in Europe and Central Asia, which are home to 152 million people, which is only $31 \%$ of the population in this region. Of these, just over 3 million people are MPI poor."(www.ophi.org.uk/multidimensional-poverty-index). "This is the least poor region of those covered by the Global MPI, and also the region with the lowest population coverage and $2 \%$ of people in ECA are MPI poor, and the average intensity of poverty for each poor person is $38.1 \%$." (www.ophi.org.uk/multidimensional-poverty-index).

Table 04: Poverty estimations for South Asia

\begin{tabular}{|l|l|l|l|}
\hline Country & Year & \% MPI poor $(\mathrm{H})$ & \% Destitute \\
\hline Nepal & 2011 & 44.2 & 19.9 \\
\hline Pakistan & $2012 / 13$ & 44.2 & 20.7 \\
\hline Bangladesh & 2011 & 51.3 & 17.2 \\
\hline India & $2005 / 06$ & 53.7 & 28.5 \\
\hline Afghanistan & $2010 / 11$ & 66.2 & 37.7 \\
\hline
\end{tabular}

Source: Own adjustment based on www.ophi.org.uk/multidimensional-poverty-index

According to the Multidimensional poverty Index 2015, poverty estimations for seven South Asian countries in 2015 are as follows. "Afghanistan is the poorest country in South Asia, with $66 \%$ of people being multidimensional poor using $2010 / 11$ data; India (2005/6) is the next poorest with 54\%, followed by Bangladesh (2011) with 51\%, Pakistan (2012/13) and Nepal (2011) at 44\%, Bhutan (2010) at 27\%, and Sri Lanka and the Maldives at 5\%." (www.ophi.org.uk/multidimensional-poverty-index). Afghanistan, Pakistan and India claimed the highest rates of destitute population ${ }^{x}$ who were deprives from their fundamental 
needs and in compared to European Union the situation in South Asia is very pathetic and severe.

Another remarkable difference between South Asia and European Union is the nature and size of their trade. In case of bilateral trade even though India and Pakistan estimated for the first and second largest GDP values in the region Rizwanulhassan and Shafiqurrehman (2015) pointed out that the despite the fact that Sri Lanka is in the fourth place in its GDP value, in case of bilateral trade India had the largest share of $35 \%$ with Sri Lanka while $11.5 \%$ with Pakistan. The authors further pointed out due to the political tensions between India and Pakistan the bilateral trade accounted for low value. Zaman, Atif and Farooq (2011) concluded that SAARC is not successful in resolving economic issues and political tensions in its region and the member countries have ignored the prospects of having a united economy. By contrast EU not only composed the world's largest economies but their contribution for the world economy is also very much significant. The Table 05 indicates that the world share by different countries in year 2014 by their GDP contribution to the world economy.

Table 05: Contribution for the World GDP by Top ten countries 2014

\begin{tabular}{|c|l|r|r|l|}
\hline \multicolumn{1}{|l|}{ Rank } & Country & \multicolumn{1}{|l|}{2014} & World share & Continent \\
\hline 1 & United States & $17,418.925$ & $22.53 \%$ & North America \\
\hline 2 & China & $10,380.380$ & $13.43 \%$ & Asia \\
\hline 3 & Japan & $4,616.335$ & $5.97 \%$ & Asia \\
\hline 4 & Germany & $3,859.547$ & $4.99 \%$ & Europe \\
\hline 5 & United Kingdom & $2,945.146$ & $3.81 \%$ & Europe \\
\hline 6 & France & $2,846.889$ & $3.68 \%$ & Europe \\
\hline 7 & Brazil & $2,353.025$ & $3.04 \%$ & South America \\
\hline 8 & Italy & $2,147.952$ & $2.78 \%$ & Europe \\
\hline 9 & India & $2,049.501$ & $2.65 \%$ & Asia \\
\hline 10 & Russia & $1,857.461$ & $2.40 \%$ & Europe \\
\hline
\end{tabular}

Source: http://statisticstimes.com/economy/world-gdp-ranking.php

Table 05 reveals that the Germany ranks in the $4^{\text {th }}$ place by its contribution for the world GDP and U.K, France and Italy also claim higher ranking above Russia and India in terms of world share in the GDP contribution. When four countries in the European Union claimed for the highest share of the world's GDP only India seems to secure its position in the ranking in $9^{\text {th }}$ place. 
Table 06: Contribution for the World GDP by South Asian Countries (2014)

\begin{tabular}{|l|c|}
\hline \multicolumn{1}{|c|}{ Country } & $\begin{array}{c}\text { Contribution for World GDP } \\
\text { as a percentage }\end{array}$ \\
\hline Afghanistan & $0.06 \%$ \\
\hline Bangladesh & $0.49 \%$ \\
\hline Bhutan & $0.01 \%$ \\
\hline Sri Lanka & $0.20 \%$ \\
\hline Maldives & $0.01 \%$ \\
\hline Nepal & $0.06 \%$ \\
\hline Pakistan & $0.82 \%$ \\
\hline
\end{tabular}

Source: Own adjustment based on https://www.quandl.com/collections/economics/gdp-as-share-ofworld-gdp-at-ppp-by-country

Table 06 indicates that the contribution by the South Asian countries for the world GDP. Except India (Table 05) other countries accounted for very low value in their contribution for the world GDP which is even less than one percent from world GDP. Even Pakistan the second largest economy of the South Asia does not contribute largely for the share of world GDP. By contrast number of EU countries shares the world GDP significantly and this is another outstanding difference between South Asia and European Union.

According to Zaman, Atif and Farooq (2011, p.16) during 1980- 2002 the intra state trade among SAARC countries was less than $2 \%$ which shows a low level of integration in South Asia while the intra-state trade among European countries was $62 \%$ in the given period. "The regional trade in South Asia is dismally low at 4 percent as compared with the regional trade of the European Union at 67 percent" (Kher 2012, p. 3). These facts concluded that South Asian intra-State trade need to grow largely while European Union has been successfully progressed in increasing its intra-state trade and the world's market share.

Fear psychosis of Pakistan and other smaller nations regarding the big brother policy of India is one outstanding cause for the low level of intra-state trade in the South Asia. Das (1992) describes that Pakistan feared that the intensive cooperation in hard core economic areas would bring more benefits and advantages for India while facilitating Indian dominancy in the region. Adding to the same idea Kher (2012) pointed out that many South Asian countries perceived the fact that increased trade within the region means increased dominance of India over the region and not as a means of getting access to larger markets. The author added therefore smaller states such as Nepal and Bangladesh tend to import from extra regional suppliers at higher $\operatorname{cost}^{x i}$ and they even feel hesitant to accept the Indian investments. India is not only a regional economic giant but also a world's top trading nation even though the failed political relations among its neighborhood constrained the expansion of trade within the region ${ }^{x i i}$. Contrary to this situation in South Asia the European 
Union has achieved the goal of establishing a Common Commercial Policy whereas SAARC has not yet attempted on such.

Another contrasting factor between European and South Asian nations is the level of human development. Many countries in South Asia indicate low level of value in human development sectors such as, per capita income, and life expectancy compared to the European nations as indicated by the Human Development Index (HDI). The following Table 07 depicts different levels of Human Development.

Table 07: Human Development Index Groups according to HDI value (2013)

\begin{tabular}{|l|l|}
\hline Human Development Index Groups & Human Development Index (HDI) Value \\
\hline Very high human development & \\
\hline High human development & 0.890 \\
\hline Medium human development & 0.735 \\
\hline Low human development & 0.614 \\
\hline
\end{tabular}

Source: http://hdr.undp.org/en/content/table-1-human-development-index-and-its-components

According to Table 07 there are four categories of Human Development levels and the following Table 08 indicates to which level of Human Development that the Europe and South Asia belong in to. Those countries of HDI value above from 0.890 considered to be having very high human development while those who are below 0.493 considered as having low human development state in their countries. When composing the Human Development Index number of factors has been considered such as the life expectancy at birth, Mean years of schooling, Expected years of schooling, and Gross National Income (GNI) per capita.

Table 08: Human Development Index for different regions

\begin{tabular}{|l|l|}
\hline $\begin{array}{l}\text { Human Development Index } \\
\text { Groups }\end{array}$ & $\begin{array}{l}\text { Human Development Index } \\
\text { (HDI) Value 2013 }\end{array}$ \\
\hline Europe and Central Asia & 0.738 \\
\hline South Asia & 0.588 \\
\hline
\end{tabular}

Source:http://hdr.undp.org/en/content/table-1-human-development-index-and-its-components

Table 08 connotes that Europe and Central Asia belong to High Human Development category while South Asian countries belong to Low Human Development category. The difference between European Union countries and South Asia is huge and Table 09 reveals Human Development level of EU countries without the Central Asia. 
Table 09: European Union countries having very high human development value (2013)

\begin{tabular}{|l|l|}
\hline Number of countries & $\begin{array}{l}\text { Very high human } \\
\text { development }\end{array}$ \\
\hline 1. & Netherlands \\
\hline 2. & Germany \\
\hline 3. & Denmark \\
\hline 4. & Ireland \\
\hline 5. & Sweden \\
\hline 6. & United Kingdom \\
\hline 7. & France \\
\hline 8. & Austria \\
\hline 9. & Belgium \\
\hline 10. & Luxembourg \\
\hline 11. & Finland \\
\hline 12. & Slovenia \\
\hline 13. & Italy \\
\hline 14. & Spain \\
\hline 15. & Czech Republic \\
\hline 16. & Greece \\
\hline 17. & Cyprus \\
\hline 18. & Estonia \\
\hline 19. & Lithuania \\
\hline 20. & Poland \\
\hline 21. & Slovakia \\
\hline 22. & Malta \\
\hline 23. & Portugal \\
\hline 24. & Hungary \\
\hline 25. & Croatia \\
\hline 26. & Latvia \\
\hline
\end{tabular}

Source: Own adjustment based on http://hdr.undp.org/en/content/table-1-human-developmentindex-and-its-components

Out of 28 European Union countries except for Romania and Bulgaria all the other 26 countries belong in to the Very High Human Development category while Romania and Bulgaria belong to the second highest level of HDI which is the High Human Development. Therefore those people who live in EU region enjoy high level of Human Development compared to the South Asian countries. In terms of education many South Asian countries still have considerable amount of population who are uneducated and there are many differences among the member states in the educational levels. But in Europe they have already achieved many of their objectives and they have strong, developed economies too. 
Table 10: Contrasting factors between EU and SAARC Countries

\begin{tabular}{|l|l|l|}
\hline Indicators & EU & SAARC \\
\hline Urban population (\% of total) & 75 (Year 2014) & 33 (Year 2014) \\
\hline Rural population (\% of total population) & 25 (Year 2014) & 67 (Year 2014) \\
\hline Internet users (per 100 people) & 78.1 (Year 2014) & 16.6 (Year 2014) \\
\hline $\begin{array}{l}\text { CO2 (Carbon Dioxide) emissions (metric tons per } \\
\text { capita) }\end{array}$ & 7.1 (Year 2011) & 1.4 (Year 2011) \\
\hline Energy use (kg of oil equivalent per capita) & 3,296 (Year 2013) & 565 (Year 2012) \\
\hline Life expectancy at birth, total (years) & 80 (Year 2013) & 67 (Year 2013) \\
\hline Labor force participation rate, female & 51 (Year 2013) & 31 (Year 2013) \\
\hline Research and development expenditure (\% of GDP) & $2.06 \%($ Year 2012) & 0.76 (Year 2011) \\
\hline
\end{tabular}

Source: Own adjustment based on http://data.worldbank.org/country

Apart from some of the factors mentioned previously comparing EU and SAARC, the Table 10 indicates more factors that reveal the contrasting nature of South Asian and European Union countries. There is a sharp division between the urban and rural population spread in the two regions. Many developed countries have larger urban population since they gathered in urban areas of modernization and also by this time many rural areas in these countries have been modernized and have converted in to urban areas. In EU zone out of total population $75 \%$ live in urban areas whereas in South Asia only $33 \%$ belong to the urban population. The rural population of the South Asian countries are high in number (67\%) compared to the EU rural population of $25 \%$.

Another contrasting factor between the two regions is that per hundred people $78.1 \%$ make use of internet in the EU countries while in SAARC region it is four times lesser than that of the EU. On one hand it depicts the slow growth of technology in South Asia as well as the less adoption to the technology and usage by the people in South Asia.

CO2 emission and energy use are significant factors indicating a country's industrial development. In that case CO2 emission (metric tons per capita) for EU countries is 7.1 in 2011 while it is five times lesser in South Asia. Similarly energy use (kg of oil equivalent per capita) in EU is 3,296 which are five times more than the energy use of South Asia.

The research and development expenditure of a country indicates the level of its new innovations and the adoption of new technology. Moreover when new innovations are done 
they increase the human capital development of the people since it required educated and skillful msn power to grasp the new technology and innovate the new technology. In that case the EU allocation by the GDP for Research and Development is $2.6 \%$ in 2012. But in South Asia it is even less than one percent (0.76\%) of the GDP. Lack of funding on research and development create lesser innovations and the people are also not familiar with the new technology. Therefore they have to depend upon the developed nations for technology. The adoption and absorption of the foreign technology by these developing countries create a problem for them as long as they do not have necessary human capital compatible with the new technology. Again these developing countries have to depend on the foreign expertise which increases their dependency further.

One of the important factors of Human Development Index is the life expectancy at birth. In year 2013 it was 80 years in EU and 67 years in SAARC. As described in the previous sections of this paper, the Human Development level of the two regions is very contrasting and many of the South Asian people do not enjoy better life in many aspects compared to those who live in EU countries. This contrast prevails in the gender issues as well. For instance in EU countries the Labor force participation rate of female is 51 in 2013 while it is only 31 in South Asia.

As mention before the political tensions among the SAARC nations hugely affect the regional cooperation in negative manner due to many intra-state conflicts prevail among them. European nations have experienced two World Wars in the history. The arch enemies such as Germany and France during the war period later became mutual partners in the regional cooperation in attaining economic prosperity. According to Zaman, Atif and Farooq (2011) and Kher (2012) Europe is relatively homogeneous in many aspects whereas the cultural, religious, ethnic differences of South Asia constrained the regional cooperation as it is contaminated with many intra-state conflicts. While the European Union succeeded in resolving its political disputes despite the fact that many of them were involved in two major World Wars and also been arch enemies of one another, South Asia had failed to brush aside their differences and cooperate for better regional integration. Bhargava (1998, p. 7) concluded that while European Union has achieved peace and prosperity, "the people of South Asia have yet to feel tangible and visible benefits of cooperation. SAARC has hardly progressed beyond signs and symbols. At present more rhetoric than action is evident."

One of the most significant achievements of the European Union accomplishing the political integration is that they are working together for a Common Foreign and Security policy. This policy intends to formulate a common policy for security and political issues. The member states have determined to work together on these high political matters whereas in SAARC the contentious issues pertaining to the member states have been excluded from discussion at the SAARC forums. In the SAARC Charter under the Article X General Provisions, it is stated that "Bilateral and contentious issues shall be excluded from the deliberations". xiii By contrast the European Union has begun the political integration process 
and now that they even formulate Common Foreign and Security policy for the region. Similarly the organization flexibility of the European Union also very much commendable compared to the rigid stand of the SAARC nations in revising the regional organization. European Union has adopted important institutions such as European Parliament, European Court of Justice and Council and Commission along with certain other institutions such as Economic and monetary union. By contrast Bhargava (1998, pp. 9-10) pointed out "in SAARC there is resistance to the idea of revising its Charter or even the Terms of Reference of the Charter bodies. The proposal of some Member States of SAARC to explore possibilities of sub-regional cooperation has raised a furor and some unnecessary controversy."

In case of human rights and fundamental freedoms European Union deliberately attempted to establish democracy and secure the fundamental rights of citizens in the region whereas SAARC has not granted special concern on that. According to the Copenhagen Criteria ${ }^{\text {xiv }}$ those who expect the membership of European Union must have the Stability of institutions guaranteeing democracy, the rule of law, human rights and respect for and protection of minorities.

Another significant difference between SAARC and the EU is their transnational networks. Even though there are trans- European networks in the fields of transport, telecommunications, energy and environment Bhargava (1998) added that there are no trans-South Asian networks in these crucial areas. Similarly in information and Communication EU consists of huge network of information available for citizens, academics and scholars while SAARC network is too much lagging behind to that of the EU. One disadvantage of the lack of information among the South Asian nations is that they are unaware of the prevailing trade opportunities within the region and tend to import from extra regional bodies at higher price. The SAARC Heads of State agreed "that inadequate communication facilities amongst the Member States were a major hindrance to closer economic co-operation. They stressed the importance of developing infrastructure and adequate communication networks among Member States to reinforce the process of economic co-operation." (Declaration of $9^{\text {th }}$ SAARC Summit, 1997).

\section{EU as a model and lesson for SAARC}

Börzel and Risse (2009, p. 6) describes that the "EU is often considered as the "gold standard" of regional integration" and it is treated as the "conceptual universe". They further added "in practical politics, the EU has served as a major reference point in various attempts of region building" (Börzel and Risse, 2009, p. 6). This paper attempts to analyse how far the European model could be useful for the regional integration in South Asia. 
According to Wolf and Sauerborn (2012) South Asian region has not made considerable performances to attain comprehensive political or economic integration within the region and at the same time the European model could not be neatly fit in to the South Asian region. The authors further added even though Europe has achieved peace, prosperity and democracy successfully, SAARC is still unable to reach beyond rhetoric of regional cooperation. Due to various intra-state conflicts and specially the Indo-Pakistan crisis over Kashmir issue pertaining to greater trust deficit among South Asian countries remain as a stumble block towards prosperous economic integration. Kher (2012) added that India has not been able to build up sufficient confidence with its member countries in its dedication to non-interference and open up its arms to provide better leadership and also attempt to resolve bilateral tensions. Thus South Asia considerable lacks effective and trust worthy leadership unlike in Europe.

Despite the fact that France, Germany, U.K and Italy were arch enemies during the World War period, they were able to unite for economic and political integration unlike in South Asia. The reluctance of the South Asian leadership to open up their economies delayed the adoption of policies for economic liberalization domestically. It took more than five decades after the independence in 1940s to sign a Free Trade Agreement in South Asia. The trust deficit among the political leaders as well as the same attitude of people in South Asia who hesitate to make decisions towards a supra national cooperation constrained the adoption of European model in South Asia.

Moravcsik (1998, p.18) concluded that the national preference making in Europe has been greatly influenced by economic interests and geopolitical interests. In that case South Asian leadership should recognize the timely need and importance of having concrete economic agenda to accelerate economic integration within the region which could perhaps inculcate spillover effects towards the initiation of political integration later. According to functionalism and neo functionalism described above, the spill-over effect in economic sectors and its benefits encourage people to embrace regional cooperation more enthusiastically. But according to inter-governmentalists the nations would not easily transfer their decision making authority in issues pertaining to high politics and states are the only legal actors of decision making. The South Asian approach towards regional integration represents more of the intergovernmental ideas rather than functional or neo-functional principles due to the fact that rigid political disinclination and absence of strong political will towards both political integration and economic integration.

Kher (2012, p. 18) pointed out "South Asian integration efforts have been mild and characterized by lack of political will. By contrast, the signing of the Treaty of Rome in 1957, establishing the EU, was preceded by strong sentiments for solidarity in the region. There was strong political will to unite and create a prosperous and peaceful bloc of European nations." It is difficult to expect the spill-over effect could bring the political integration in 
South Asia through a natural phenomenon. It requires deliberate political will and public consent and their participation too. Moreover the lack of similar types of governments and democratic ones also constrain the political integration to a greater deal among South Asian countries whereas in Europe, the member states of EU are all democratic countries.

The non-homogeneous nature of the South Asia is another strong reason for the above trust deficit among the people and therefore the European hope of adopting Federalist structure is just an illusion for South Asia which they do not even dreamt about. The tolerance, patience, compromise and reciprocity as the main moral values needed for greater cooperation towards political integration which will end up in the form of a federal state is unlikely to emerge in South Asia due to its reluctance to cooperate in spite of its differences.

\section{Conclusion and recommendations}

The main purpose of this paper is to comparatively analyse the regional integration in South Asia and Europe while explaining the theoretical relevance of certain theories of integration. It was also expected to evaluate how far European integration model can be applied in to the South Asian context. The following conclusions are derived from this analysis as stated below.

Many of the integration theories describe the European integration and as stated in functionalism and neo-functionalism the concept of spill-over effect in economic sectors cannot be seriously witnessed in South Asian context. It is even difficult to expect that such spill-over would happen in South Asia due to number of constraints arise from within the region. But the Liberal intergovernmentalism is more relevant to the South Asian context in which the role of government heads and their participation in decision making is highly emphasized. The rigid decision making process constrained the structural adjustments and it is difficult to see that the South Asian nations incline to transfer their sovereignty powers to the regional body. SAARC seems to be continue to stay as an intergovernmental organization and there is minimal attempt to convert it in to a supra national body which is very much insignificant. SAARC requires restructuring its institutions to discuss the contentious issues among member states more openly and without a proper mechanism initiated through the regional arrangement it is unlikely to solve the political tensions among them. As a regional organization SAARC could provide a better platform for these discussions.

The comparative analysis of SAARC and EU region depicts that there are many contrasting aspects of the two regions in terms of economic and political integration. SAARC is still struggling to overcome certain barriers towards the successful implementation of its Free Trade Agreement while EU has passed all the stages of economic integration and even 
begun the political integration process. In terms of economic development, human capital development, education, poverty alleviation, and intra- trade, there are huge differences between the two regions. SAARC region is very much slow in its economic integration process compared to the EU countries and the former is lagging behind EU countries in many aspects of the development.

Comparative analysis moreover connotes that the sharp diversity between the two regions in terms of trade liberalization, economic and political integration, urbanization, industrialization, human development and economic development constrained the adoption of European model in the way it was adopted to accelerate European integration. As mention above the positive spill-over effect and the adoption of federalist framework in South Asia is just a utopia since the political tensions among the member states constrained the implementation of the basis premises of economic integration in the region. Even though there are many lessons to be learnt from the European model, the acceptability of these lessons and the adaptation of them in South Asia is mere illusionary hope with the existing and unresolved and seemingly unresolvable political tensions among the member states.

SAARC desperately requires many reforms to accelerate its economic integration and promotion of social welfare of the people in the region. The promotion of people to people contact has been neglected too much in the region and it has been confined only to the exchange and visits of high level governmental authorities.

Inconvenient visa processes needs to be reevaluated in order to make it easier for the people to contact them through the region. Track Three diplomacy ${ }^{2}$ and Track four diplomacy $^{3}$ should be promoted to increase the interaction among businessmen, civil societies, and non-governmental organizations and interests groups in the region to open up more avenues for fruitful dialog among them which could help to accelerate the regional integration.

In case of trade there must be well defined long term programmes to facilitate trade. Both tariff and non-tariff barriers should be removed gradually and need for financial institutions to support capital requirements of the region should be taken in to grant. The inadequate transport system is not only time consuming but also increases the cost of trade within the region. If the regional cooperation has been increased this would have been avoided. By

\footnotetext{
${ }^{2}$ Apart from conducting intergovernmental level relationships only through the Heads of the State which is known as the Track one diplomacy, there are other ways and means of uniting the nations for better cooperation. One such diplomatic method is Track Three diplomacy which could do peacemaking through trade and commerce. By providing more economic opportunities in respective countries it is expected to strengthen up friendships and mutual understanding since it could work as informal channels of communication in promoting regional cooperation.

${ }^{3}$ Track four diplomacy involves various private sector organizations and citizens who could involve in development activities.
} 
integrating the economies in the region ultimately it will provide larger markets for the people with abundance of goods and services at a lower price. Final goal of a regional organization should foster the economic and social well-being of the people in its region. SAARC should attempts to achieve this goal considering the betterment of the people.

Finally in order to bring all these benefits for the people in South Asia it is required to eradicate the political tensions among the member states which had been the greatest hurdle that constrained its cooperation so far. The European nations set a very good example for this. Even after waging two World Wars in Europe and been the arch enemies of one another during the war time they agreed to develop Europe by promoting mutual understanding and cooperation soon after the end of Second World War. Contrastingly South Asia is still reluctant to promote their political will for cooperation and unless both the political leadership and the public agreed and committed for greater cooperation, the economic and political integration in South Asia would be a faint mirage in the future. In South Asia apart from domestic economic development and establishment of real democracies within member states, what require mostly for the successful integration at region level are mutual understanding, tolerance, compromise and reciprocity which are essential moral values for any successful regional arrangement.

\section{References}

BHARGAVA, K.K. (1998) European Union (EU) - South Asian Association for Regional Cooperation (SAARC): Comparisons and Prospects of Cooperation, Center for European Integration Studies.

BÖRZEL, T.A., AND RISSE, T. (2009) The Rise of (Inter-) Regionalism: The EU as a Model of Regional Integration. Annual Convention of the American Political Science Association, Canada.

CASTALDI, R. (2007). A federalist framework theory of European integration. Centre for studies on federalism, Italy.

DAS, D.K. (1992). SAARC regional co-operation and development. New Delhi: Deep \& Deep Publications.

Declaration of $9^{\text {th }}$ SAARC Summit, (1997).

HAAS, E.B. (1958) The Uniting of Europe California intergovernmentalist approach. Journal of Common Market Studies. 1958, Vol.31, No.4, s. 473-524.

HAAS, E.B. (1976) Turbulent Fields and the Theory of Regional Integration. International Organization. 1976, Vol. 30, No.2, s. 173-212. http://dx.doi.org/10.1017/s0020818300018245

KHER, P. (2012) Political economy of regional integration in South Asia. UNCTAD.

MOGA, T.C. (2009) The Contribution of the Neofunctionalist and Intergovernmentalist Theories to the Evolution of the European Integration Process. Journal of Alternative Perspectives in the Social Sciences. 2009, Vol.1, No.3, s. 796-807. 
MORAVCSIK, A. (1991) Negotiating the Single European Act: National Interests and Conventional Statecraft in the European Community. International Organization, 1991, Vol. 45, s. 19-56. http://dx.doi.org/10.1017/s0020818300001387

MORAVCSIK, A. (1993) Preferences in power in the European Community: A liberal intergovernmentalist approach. Journal of Common Market Studies, 1993, Vol. 31, No.4, s. 473-524. http://dx.doi.org/10.1111/j.1468-5965.1993.tb00477.x

MORAVCSIK, A. (1998). The choice for Europe: Social Purpose and state power from Messina to Maastricht, London, Ithaca, NY: Cornell University Press.

MORAVCSIK, A., \& SCHIMMELFENNIG, F. (2009). Liberal Intergovernmentalism. In Wiener, A., \& Diez, T. (Eds.), European Integration Theory. Oxford, Oxford University Press.

POLLACK, M.A (2000). International relations theory and European integration. European University Institute, Italy.

REDMOND, J. (2011). Intergovermentalism and supranationalism in European Politics: theories of explanation. In Pocock, S., \& O'Reilly, B. (Eds.), Social and Political Review. Trinity College, Dublin.

RIZWANULHASSAN, M., \& SHAFIQURREHMAN (2015) Economic Integration: An Analysis of Major SAARC Countries. A Research Journal of South Asian Studies, 2015, Vol.30, No.1, s. 95 - 105.

WOLF, S.O., \& SAUERBORN, D (2012) The EU story: Can it offer inspiration for SAARC?. Political Column in South Asian Politics, Dhaka.

ZAMAN, Q., ATIF, M., \& FAROOQ, M. (2011) Standard of Education and Economic Conditions are the Main Causes of the Failure of SAARC: A comparative study of SAARC and EU. Interdisciplinary Journal of Research in Business, 2011, Vol. 3, s. 15-22.

\section{Web references}

http://www.sipri.org/research/.../milex/milex_database/milex-data-1988-2014.

http://data.worldbank.org/income-level/HIC

http://data.worldbank.org/country)

http://statisticstimes.com/economy/world-gdp-ranking.php

https://www.quandl.com/collections/economics/gdp-as-share-of-world-gdp-at-ppp-by-country

http://hdr.undp.org/en/content/table-1-human-development-index-and-its-components

http://ec.europa.eu/enlargement/policy/conditions-membership/index_en.htm

http://europa.eu/eu-law/decision-making/treaties/index_en.htm

www.ophi.org.uk/multidimensional-poverty-index

(http://europa.eu/about-eu/eu-history/index_en.htm)

(http://eur-lex.europa.eu/legal-content)

http://articles.economictimes.indiatimes.com/2014-06-22/news/50772421_1_Subramanian-swami-SAARC-

world-peace-forum 


\begin{abstract}
${ }^{\mathrm{i}}$ Rizwanulhassan and Shafiqurrehman (2015, p. 96) describes that "due to cautious and precarious behavior of these nations the process of regional integration was very slow". Similarly Zaman, Atif and Farooq (2011, p. 15) concluded that in their study which intends to compare the performances of EU and SAARC and as result they found that "EU is proved to be very successful in achieving their goals while, SAARC has failed to retain it." Kher (2012, p. 4) also added that "Several empirical studies have concluded that most of the preconditions required for successful regional integration are not present in South Asia."
\end{abstract}

\begin{abstract}
ii "Neo-functionalism and intergovernmentalism - have underpinned and shaped the European integration process since the inception of what is today called the European Union (Moga, 2009, p.796). "Federalist and neo-functionalism6 both favoured a European federation, but proposed different views about how to establish it. The federalists suggested to elect a European Constituent Assembly to draft a European Constitution to establish the European federation [Spinelli 1950, now in Levi e Pistone (eds.) 1973]. The functionalists considered such a jump

impossible at the time, and called for a gradualist path, which starting from economic integration would lead to political union slowly but surely and without a break. This is the classical dichotomy of federalism and neo-functionalism, and generally here the story ends. But there is an important following. (Castaldi, 2007, p.29)
\end{abstract}

iii Ernst B. Haas is Robson Research Professor of Government at the University of California (Berkeley). This paper is part of the project en titled" Studies on International Scientific and Technological Regimes, " Institute of International Studies, University of California, Berkeley. He is grateful to the Rockefeller Foundation for financial support and to Richard Gunther and Michael Hatch for research assistance. (Haas, 1976, p. 173)

iv "For intergovernmentalists, Member States are rational actors who seek to achieve the best possible outcome for their state, in terms of goals like wealth, security and power (Moravcsik, 1993, p 481). Thus they are heavily involved in policies that are likely to affect them, and this is how intergovernmentalists argue for their dominance in determining policy at the European level. An example of such an argument surrounds the formation of Economic and Monetary Union". (Redmond, 2011, p.100).

$\checkmark$ The European Union is set up with the aim of ending the frequent and bloody wars between neighbours, which culminated in the Second World War. As of 1950, the European Coal and Steel Community begin to unite European countries economically and politically in order to secure lasting peace. The six founders are Belgium, France, Germany, Italy, Luxembourg and the Netherlands. The 1950s are dominated by a cold war between east and west. Protests in Hungary against the Communist regime are put down by Soviet tanks in 1956; while the following year, 1957, the Soviet Union takes the lead in the space race, when it launches the first man-made space satellite, Sputnik 1. Also in 1957, the Treaty of Rome creates the European Economic Community (EEC), or 'Common Market'. (http://europa.eu/about-eu/euhistory/index en.htm).

vi It was signed in 17 February 1986 (Luxembourg) / 28 February 1986 (The Hague) and entered into force: 1 July 1987. The purpose was to reform the institutions in preparation for Portugal and Spain's membership and speed up decision-making in preparation for the single market and extension of qualified majority voting in the Council (making it harder for a single country to veto proposed legislation), creation of the cooperation and assent procedures, giving Parliament more influence. (http://europa.eu/eu-law/decision-making/treaties/index_en.htm).

vii The Schengen area and cooperation are founded on the Schengen Agreement of 1985 . The Schengen area represents a territory where the free movement of persons is guaranteed. The signatory states to the agreement have abolished all internal borders in lieu of a single external border. Here common rules and procedures are applied with regard to visas for short stays, asylum requests and border controls. Simultaneously, to guarantee security within the Schengen area, cooperation and coordination between police services and judicial authorities have been stepped up. Schengen cooperation has been incorporated into the European Union (EU) legal framework by the Treaty of Amsterdam of 1997. However, all countries cooperating in Schengen are not parties to the Schengen area. This is either because they do not wish to eliminate border controls or because they do not yet fulfil the required conditions for the application of the Schengen acquis. (http://eur-lex.europa.eu/legal-content)

viii Signed in 1992 to prepare for European Monetary Union and introduce elements of a political union (citizenship, common foreign and internal affairs policy). Main purpose was the establishment of the European Union and introduction of the co-decision procedure, giving Parliament more say in decision-making. New forms of cooperation between EU 
governments - for example on defence and justice and home affairs. (http://europa.eu/eu-law/decisionmaking/treaties/index_en.htm)

${ }^{i x}$ Rizwanulhassan and Shafiqurrehman (2015, p. 98) concluded that "A sharp diversity exists in South Asia which appears in a range of macroeconomic indicators, as India the most populous in the region and second largest in the world while Nepal is very small country ranks 42 in world population".

${ }^{x}$ Measure of destitution, identifies a subset of poor people as destitute if they experience a number of extreme deprivations like severe malnutrition, losing two children, having all primary-aged school children out of school, and using open defecation. The destitution results for South Asia (not covering Bhutan, Maldives or Sri Lanka) are significant. Afghanistan has the highest rate of destitution of $38 \%$, followed by India at a troubling $28.5 \%$ (i.e. over 340 million people). But interestingly Bangladesh has much lower rate of destitution than either Nepal or Pakistan, showing that the country has alleviated the worst forms of deprivations. (www.ophi.org.uk/multidimensional-poverty-index).

${ }^{x i}$ Kher $(2012$, p.7) further describes that "South Asian countries trade little with each other but trade much with other nations of the world particularly with North America and Europe. The composition of each South Asian country's exports to these regions is almost similar. Textile, readymade garments, leather, agricultural products constitute a chunk of the export items while petroleum and capital intensive goods are mostly imported."

xii According Sharma (2010) "while India emerges a bigger player on the global stage, its neighbourhood policy remains a tight rope walk in a politically high-risk, yet profitable zone. Geo-political compulsions have restrained SAARC to unleash the business potential of South Asia yet"

xiii Recently Senior BJP leader, Subramanian Swamy expressing his opinion stated that "SAARC should shed the rule barring discussion on contentious bilateral issues" and agree to a larger role for China and the US to improve its functioning,"(http://articles.economictimes.indiatimes.com/2014-06-22/news/50772421 1 subramanian-swamy-saarcworld-peace-forum)

xiv In order to obtain the membership of EU it is required by the candidate states to fulfill certain criteria. These were mainly defined at the European Council in Copenhagen in 1993 and are hence referred to as 'Copenhagen criteria'. Countries wishing to join need to have: stable institutions guaranteeing democracy, the rule of law, human rights and respect for and protection of minorities; a functioning market economy and the capacity to cope with competition and market forces in the EU; the ability to take on and implement effectively the obligations of membership, including adherence to the aims of political, economic and monetary union.( http://ec.europa.eu/enlargement/policy/conditionsmembership/index_en.htm) 